\title{
The Influence of Culture, Social, Personal, and Psychological Toward the Behavior of Choosing Islamic Finance: A Study in the Community of Aceh Province Indonesia
}

\author{
M. Yasir Nasution ${ }^{1}$, Saparuddin Siregar ${ }^{2}$, Hidayati Siregar ${ }^{3}$ \\ 1,2,3 Universitas Islam Negeri Sumatera Utara, Indonesia \\ Siregarhidayati824@gmail.com
}

\begin{abstract}
The high demand for motorbikes in the people of Aceh Province has led to an increase in the amount of motorcycle financing in the Province of Aceh. The purpose of this study is to find out and analyze how the behavior of the people of Aceh Province in choosing Islamic finance as a place for motorcycle financing. This study also aims to determine the obstacles and efforts made by Islamic finance companies so that the people of Aceh choose Islamic finance as a place of financing. Type of research is quantitative-qualitative method. The analysis technique used in quantitative research is the Structural Equation Model using AMOS 22.1 software, while qualitative research data are obtained through observation, interviews and documentation. The data analysis technique used in this study is an interactive model analysis consisting of data collection, data reduction, data presentation and conclusion drawing. This study produced cultural variables that produced $P$ values $(0.703)$, social variables with $P$ values (0.070) and psychological variables with $P$ values (0.395). Each of these variables does not affect the behavior of the people of Aceh Province in choosing Islamic finance as a place of financing. While the personal variable has a positive and significant effect on the P value (0.003) which is below the critical value of 0.05. While cultural, social, personal and psychological variables simultaneously do not affect people's behavior in choosing Islamic finance. Cultural variables on personal, cultural on psychological and social on psychological have a positive and significant effect, where each $P$ value is brought to a critical value of 0.05. Personal variables and psychological variables do not have an indirect influence on the behavior of the people of Aceh Province in choosing Islamic finance with culture as an intervening variable. Likewise, personal and psychological variables do not have an indirect influence on the behavior of the people of Aceh Province in choosing Islamic finance with social as an intervening variable.
\end{abstract}

Keywords

consumer behavior, Islamic finance

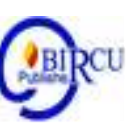

\section{Introduction}

At this time the need for motorized vehicles for the community has become a need that cannot be denied. This can be seen from day to day the number of motorized vehicles in the community continues to increase. This shows the level of interest of the community to own two- and four-wheeled motorized vehicles. Motorized vehicles are becoming "basic necessities" and no longer a luxury item. Having a motorized vehicle is a must to support the activities carried out every day. Likewise with the people of Aceh Province, which can be seen from the increase in motor vehicle ownership. This is evidenced by the 
development of the number of motor vehicles in Aceh Province from 2017 to 2019 which experienced an increase in each mode of transportation with an average percentage increase of $7.07 \%$ where the largest number of motorcycles was with a percentage of $15.63 \%$. Meanwhile, according to Darmawan the number of conventional motorcycle financing customers is greater than the motorcycle finance customers in Islamic Finance in Aceh Province. However, sometimes people are constrained by funds to own motorized vehicles. Along with the phenomenon that arises in the midst of society, there are banks and non-bank institutions that offer lucrative financing facilities.

Entering the 2000 decade the financial services industry in Indonesia experienced a very rapid development that demanded business financing to be able to adjust to the needs desired by the community itself which is increasingly complex. The role most desired by the public is the need to provide funds for investment, business capital or even to meet consumer goods. With the rapid development of the financing service industry activities, the government in this case the Ministry of Finance was asked to optimize its role as a regulator and supervisor of financing service activities through policy efforts that lead to the development of a sustainable financing service industry. One of the efforts of the Ministry of Finance to optimize its role is through enhancing the fostering and supervision functions on an ongoing basis with the aim of ensuring that the management of financing service industry activities is in accordance with applicable laws and regulations, including sharia- based financing.

The emergence of the Islamic financial system as part of the concept of Islamic economics which has the aim to base Islamic values and ethical systems in the economic field and is expected to be able to answer the community's need for the existence of Islamic financial institutions. Islam encourages freedom of doing business and financial transactions based on several prohibitions, ethics, and norms. In addition to some major prohibitions, Islamic law sets a set of norms and other restrictions to avoid unreasonable profits and injustice. For this purpose, sharia has identified several elements that must be avoided in commercial or business transactions. Thus Islamic finance is a financial institution that has a view of the concept of pleasure between finance and consumers and special attention in Islam is usury.

It cannot be denied if the development of finance companies cannot be separated from conventional banking and Islamic banking, so in this study the authors are interested in studying one of the finance companies in Indonesia, especially in Aceh Province which has enormous Islamic economic potential development, this is because the province of Aceh is an area that implements Islamic sharia as a whole (kaffah) but the growth of sharia financing in Aceh Province is not optimal and significant compared to the lives of the people of Aceh Province which are bound by sharia provisions who are still interested in using conventional based financing.

Empirical studies related to purchasing decisions by Mananeke \& Rotinsulu (2017), Lubis \& Kartikasari (2009), support the hypothesis while Gunawan (2019), Susanti, Qomariah \& Anwar (2017) rejects the hypothesis. In this study, the factors that influence the behavior of the people of Aceh Province in sharia financing will be discussed, which in this case concerns the cultural, social, personal and psychological aspects of the people of Aceh Province using the Koran and Hadith. Approach. On each variable studied in dissecting consumer behavior. So as to produce behavioral analysis in accordance with the shari'ah of Allah SWT. 


\section{Review of Literatures}

\subsection{Consumer Behavior}

Behavior is closely related to objects whose studies are directed at human problems. In the field of marketing studies, the concept of consumer behavior continues to be developed with various approaches. In this case there are several definitions of consumer behavior. Engel, Blackwell and Miniard (1997) stated "Consumer behavior is defined as the actions of individuals who are directly involved in obtaining and using good economic services including the decision making process that precedes and determines these actions". Consumer behavior is defined as the actions directly involved in obtaining, consuming, and consuming products and services, including the decision making process that precedes and follows this action. It was further said by Loudon and Bitta (2001) that "Consumer behavior can be defined as the process of decision making and physical activity carried out by individuals when evaluating, obtaining, using or disposing of goods and services.

Consumer behavior is very dynamic and tends to be adaptive, quickly adjust to the demand of the people who always need the public transport. Their demand is complex so that the government should create a good strategy for transport service quality (Sukesi and Yunus, 2018). In this paradigm, human behavior in social interactions is seen as a response (automatic mechanical reaction) from a number of stimuli that arise in interactions that produce purchasing decisions as in Figure 1.

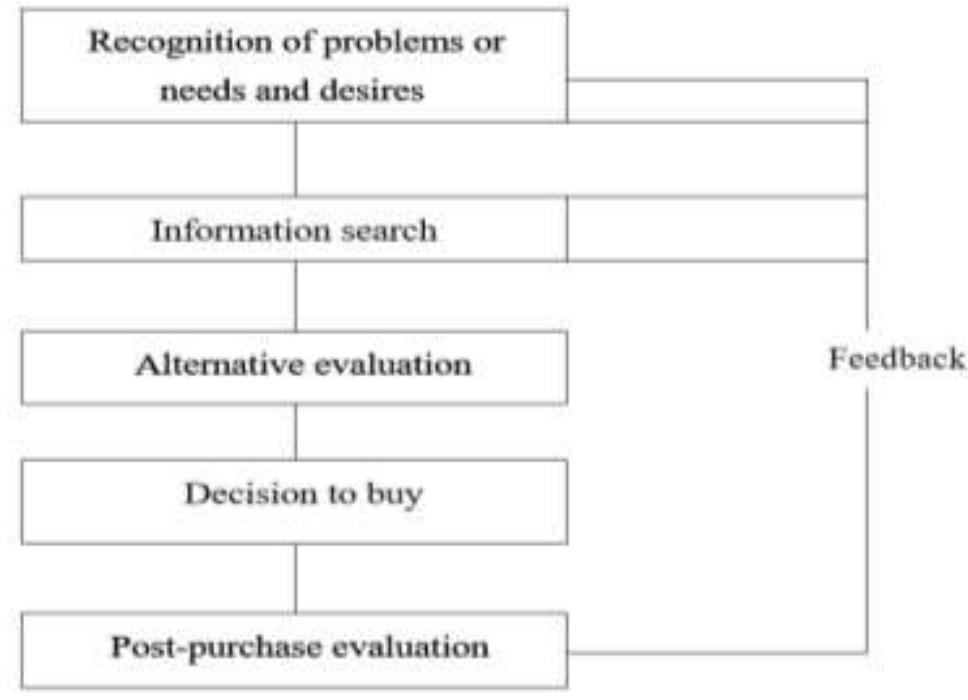

Figure 1. Purchase Decision Process

\subsection{Culture}

Culture includes human spiritual activities so that culture is not only related to physical aspects but also spiritual. Schiffman and Kanuk (2007) define culture as one classic definition states that culture is a set of socially acquired behavior patterns transmitted symbolically through language and other means to the members of a particular society. Culture in Islam is the essence of what is important in a group. Such activities give commands and prohibitions and describe what is done and not done which regulates the behavior of community members. When it was revealed, Islam did not have to erase the entire culture at that time, but accepted some and rejected some that were contrary to Islamic teachings. Islamic style also colors the culture that develops in social life which is manifested in the form of honesty, trustworthiness, visionary, and responsibility. 


\subsection{Social}

Humans are individual beings and social beings. As individual beings, humans are the unit of body and soul that forms a small part of nature, which must fulfill itself in facing its position as part of nature. Ellyana and Ismail (2020) stated that human resources as the main source and assets in the organization so that in every task implementation is of course very important where in general, in an institution both government and private, where in carrying out the duties and functions required quality human resources.

Social in Islam includes treating others in Islam based on intrinsic motives rooted in spiritual beliefs. Someone has a concern for others who are driven by the desire to seek the pleasure of Allah SWT and expect reward in the hereafter. Love one another, help each other and remind one another about goodness is the character of the faithful. A Muslim must have concern for others, both for spiritual welfare, material welfare, individual needs and social needs. A Muslim opposes other Muslims such as a body or building that supports one another from one part to another. Conversely, the nature of not caring about others is an unbelieving character.

The social role in the economy has a broad scope. This activity covers various matters directly related to economic activities as well as other matters which indirectly make economic activities better. The social role in the economy includes the following: 1) Maintaining the Economic Needs of the Family, 2) Managing Zakat, Charity and Alms, 3) Providing Social Services, 4) Managing Waqf.

\subsection{Personal}

In essence, humans are whole, unique and possessive qualities as individual beings. In life, humans have needs that are intended for personal gain. Personal life is an overall need and has special and unique characteristics. A person's lifestyle is a lifestyle in the world that is expressed by one's activities, interests and opinions. Lifestyle describes a person as a whole who interacts with the environment. Lifestyle also reflects something behind someone's social class. Personality is a different psychological characteristic and everyone who views his response to the environment is relatively consistent. Personality is related to consumer behavior. Differences in consumer personality will affect behavior in choosing or buying a product, because consumers will buy goods that match their personality. People in Islam include human classification based on belief in three patterns, namely: believers, infidels and hypocrites.

\subsection{Psychological}

Psychological factors that influence consumer behavior in psychology are motivation, perception, learning processes and beliefs and attitudes. Motivation is a process of encouragement so that consumers are moved to buy a product. Psychological consumers in Islam include consumer behavior in making decisions to buy goods or services, while consumer behavior from a psychological point of view is the behavior shown by consumers in searching for, exchanging, using, valuing, managing goods or services that they think will satisfy their needs. In Islamic economics, satisfaction is known as maslahah with the understanding that physical and spiritual needs are met. Islam attaches great importance to the balance of physical and non-physical needs based on sharia values. A Muslim to achieve a level of satisfaction must consider several things, namely the goods consumed are halal, both in substance and how to get them, not to become israf (royal) and tabzir (useless). Therefore, a Muslim's satisfaction is not based on the amount of at least the goods consumed, but based on how much worship value is obtained from consumption. 


\subsection{Review of Jurisprudence towards Research Variables}

Everything that is created, discovered or developed by a group and can be taught to new communities as a way of life. Culture can also be interpreted as custom. 2) Social. Humans as social beings have relationships and are related to each other so that social processes are born. In social processes sometimes mudharat arises, then mudharat must be eliminated. 3) Classification of human person based on belief is divided into 3 patterns, namely believers, infidels and hypocrites. 4) Psychological factors can be interpreted as coming from within the individual. Humans in life will have difficulty achieving benefits but the Qur'an and the Hadith explain that difficulty brings comfort.

\subsection{Previous Studies}

Bahari \& Anshoer (2018) who examined the Cultural, Social, Personal and Psychological Effects of Purchasing Decisions on Ecotourism Consumers. This study concludes that the simultaneous influence of each independent variable on purchasing decisions is done by testing the F- test, which means that the independent variables have a significant simultaneous effect on purchasing decisions. Cultural variables that show the lowest mean value are sub-cultural indicators, in this study the items used are geographical conditions. To reach Malino Highland, easy access to transportation is needed, by working with travel agents, and by working with other parties related to transportation to introduce tourists to this place. Social variables have a relatively low average value, this shows the lack of social influence on natural tourism visitors. Indicators in this factor are the influence of friends or a group of references, family, and role and status. To increase the influence of this variable can be done by conducting sales promotions such as family or friends packages and making advertisements by involving important figures who influence on natural tourism in Indonesia. Personal variables indicating a low mean are indicators of economic conditions and self- concept. To increase the effect of this variable, more affordable pricing is needed. Psychological variables are the most dominant variables, in this variable motivation and perception items have low average values and can be improved by strengthening brand image.

Gunawan (2019) examined the Effect of Cultural, Social, Personal and Psychological Factors on Purchasing Decisions of Toyota Avanza Car Products in Surabaya. The results of the study obtained several conclusions as follows: Cultural factors have a significant positive influence on purchasing decisions of Toyota Avanza which shows that cultural factors increase the purchase decision of Toyota Avanza. Social factors do not significantly affect Toyota car purchasing decisions which indicate that social factors cannot improve Toyota Avanza car purchase decisions. Personal factors have a significant positive influence on the purchase decision of Toyota Avanza, which shows that personal factors can enhance the purchase decision of the Toyota Avanza. Psychological factors have a significant positive effect on the purchase decision of Toyota Avanza, which shows that psychological factors increase the purchase decision of the Toyota Avanza.

Pratiwi \& Mandala (2015) examined the influence of cultural, social, personal, psychological, and marketing factors on the purchase of embroidery kebaya at Jegeg Ayu Boutique in Kuta. The purpose of this study was to determine the effect of a mixture of cultural, social, personal, psychological, and marketing on purchasing decisions for embroidery kebaya at Jegeg Ayu Boutique in Kuta. This research was conducted in Jegeg Ayu Boutique Kuta, samples taken as many as 108 respondents with purposive sampling method. Data collection by distributing questionnaires. The results of this study indicate that cultural factors have a positive influence on purchasing decisions for kebaya embroidery at Jegeg Ayu Boutique in Kuta. Social factors have a positive influence on 
purchasing decisions for kebaya embroidery at Jegeg Ayu Boutique in Kuta. Personal factors have a positive influence on the decision to buy embroidery kebaya at Jegeg Ayu Boutique in Kuta. Psychological factors have a positive influence on purchasing decisions for kebaya embroidery at Jegeg Ayu Boutique in Kuta. Finally, the marketing mix has a positive effect on the decision to buy an embroidery kebaya at Jegeg Ayu Boutique in Kuta.

Ghoni \& Bodroastuti (2017) testing the Effect of Cultural, Social, Personal and Psychological Factors on Consumer Behavior (Study of Housing Purchases in Griya Utama Housing Banjardowo Semarang) Based on the results of the study it can be concluded that there is a significant direct relationship between the influence of social factors on consumer behavior. Social factors are groups of people who carefully consider the similarity in status or appreciation of people who continue to socialize among themselves, both formally and informally. Consumer behavior is also influenced by social factors such as reference groups, families, and the role and social status of consumers. Reference groups have a direct or indirect effect on a person's attitudes and behavior. Social class is sometimes in the form of a caste system where members from different castes for certain roles can change their caste, family, and parent membership in influencing purchasing decisions. The higher the relationship with friends, family and parents, the higher the decision to make a purchase.

\subsection{Conceptual Framework}

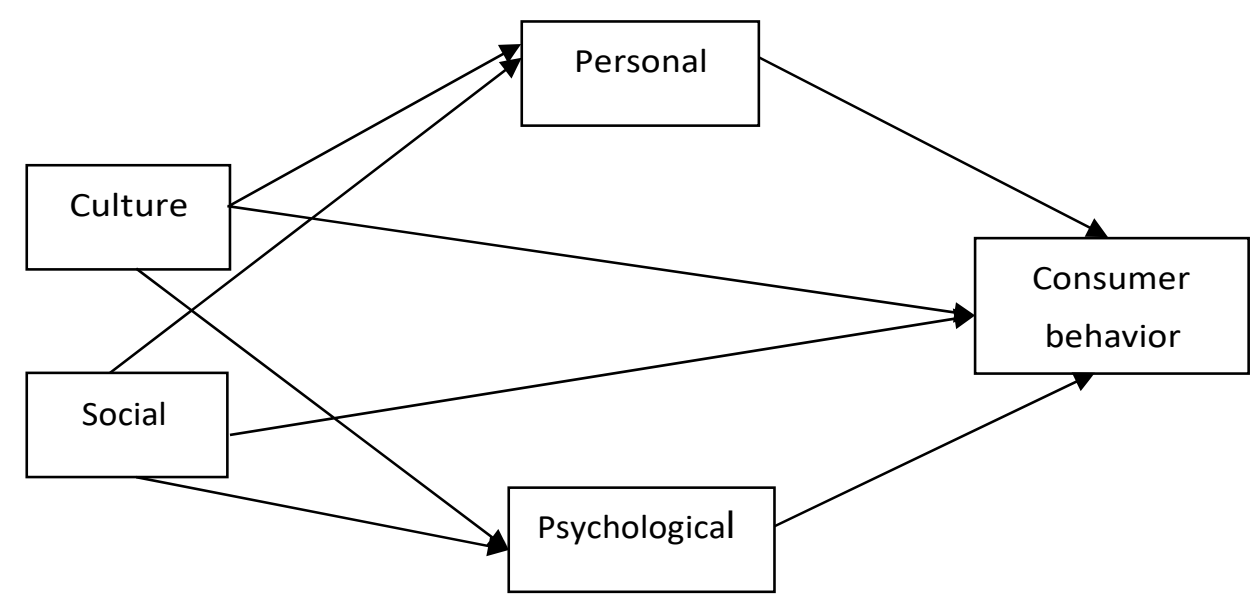

Figure 2. Theoretical Research Model

The choice of Islamic finance as a place of financing for the people of Aceh is a big hope. This is because Aceh is nicknamed the Veranda of Mecca which is a predominantly Muslim area. But in reality, there are many obstacles faced in realizing these expectations. This is caused by several factors, both internal and external to the people of Aceh itself. So to overcome this challenge, there needs to be an effort in the field of Islamic finance to consider and pay attention to the people of Aceh in choosing Islamic finance as a place of financing. Behavior of choosing consumers in this case the people of Aceh are influenced by several factors including culture, social, personal and psychological society of Aceh. 


\section{Research Methods}

This research uses quantitative research starting with ex post facto research design that is the variables studied are not controlled and manipulated by researchers, but the facts are expressed based on the measurement of symptoms that have been held or test what will happen. This is based on Kerlinger's definition which provides a limitation that non-experimental research is a systematic empirical study in which scientists cannot directly control independent variables because their manifestations have arisen or because the nature of the variables does indeed cover the possibility of manipulation. To analyze one variable with another variable used path analysis (path analysis). Path analysis requires a significant linear regression form between variables. Path analysis is used to analyze the pattern of relationships between variables to determine the direct or indirect influence of a set of causal variables (exogenous variables) on a set of effect variables (endogenous variables). Furthermore, the path analysis model is divided into three types, namely (1) correlated path model (2) mediated pathway models ( (3) independent path model. The type of model in this study is a mediated pathway model. This study analyzes the effect of one variable on other variables, namely: (1) culture, (2) social, (3) personal (4); psychological, (5) consumer behavior. Data collection tools used were questionnaires.

Future studies use descriptive research with a qualitative approach. Qualitative descriptive research aims to uncover events or facts, circumstances, phenomena that occur during the research by presenting what actually happened. This study does not make a comparison of variables in other samples and look for the relationship of variables with other variables. Qualitative research is a research method used to examine the condition of natural objects, in which the researcher is a key instrument, sampling data sources is done purposively and snowballing, collecting techniques with triangulation (combined), data analysis is inductive and the results of research emphasize.

The data used in this analysis includes all the people of Aceh Province who were determined as many as four cities and districts, namely: (1) Banda Aceh, (2) Lhokseumawe, (3) Langsa, (4) Meulaboh and to determine the community to be sampled, research on sampling techniques this by using stratified proportional random sampling technique.

Table 1. Research Samples Based on Population and Gender in Four Municipalities and

\begin{tabular}{|c|c|c|c|c|c|}
\hline \multicolumn{6}{|c|}{ Regencies in Aceh Province } \\
\hline \multirow{2}{*}{ No } & \multirow{2}{*}{$\begin{array}{c}\text { Municipality / } \\
\text { Regency }\end{array}$} & \multirow{2}{*}{$\begin{array}{c}\text { Number of } \\
\text { Communities }\end{array}$} & \multicolumn{3}{|c|}{ Number of Samples } \\
\hline & & & Man & Woman & Total \\
\hline 1 & Banda Aceh & 259.169 & 44 & 52 & 96 \\
\hline 2 & Lhokseumawe & 181.967 & 44 & 52 & 96 \\
\hline 3 & Langsa & 162.814 & 42 & 53 & 95 \\
\hline 4 & Meulaboh & 190.244 & 52 & 44 & 96 \\
\hline & Total Sample & 793.088 & 182 & 201 & 383 \\
\hline
\end{tabular}




\section{Results and Discussion}

\subsection{Results}

Table 2. Indirect Effect

\begin{tabular}{|l|ccccc|}
\hline & Social & Culture & Personal & Psychological & Consumer_behavior \\
\hline Personal & 0,991 & 0,094 & 0,000 & 0,000 & 0,000 \\
Psychological & 0,926 & 0,181 & 0,000 & 0,000 & 0,000 \\
Consumer_behavior & 0,562 & 0,023 & 0,696 & $-0,263$ & 0,000 \\
\hline
\end{tabular}

Source: results of SEM

Based on the results of the analysis of the output of the table above, it can be seen by reading the column predicting rows (column ---> row) so that there can be a direct influence of Social on personal by 0,991 , social on psychological 0,926 , social on Consumer Behavior by 0,562 . The direct influence of culture on the person is 0.094 , culture on the psychological is 0.181 , culture is on the consumer behavior by 0.023 . While the personal direct effect on consumer behavior amounted to 0.696 and psychological on consumer behavior amounted to -0.263

Table 3. Indirect Effect

\begin{tabular}{|l|ccccc|}
\hline & Social & Culture & Personal & Psychological Consumer_behavior \\
\hline Culture & 0,000 & 0,000 & 0,000 & 0,000 & 0,000 \\
Psychological & 0,000 & 0,000 & 0,000 & 0,000 & 0,000 \\
Consumer_behavior & 0,446 & 0,018 & 0,000 & 0,000 & 0,000 \\
\hline
\end{tabular}

Source: results of SEM

Based on the results of the analysis of the output table above standardized direct effects and standardized indirect effects, it appears that the indirect effect between variables is of less value (zero value) when compared to the value of direct influence. This is not in accordance with the results of the estimation model test that the Psychological variable as a variable does not mediate the effect on the Social and Consumer Behavior variable. While the estimation test results of Psychological variable models as mediating variables do not affect the Culture and Consumer Behavior variables.

Table 4. Total Effect

\begin{tabular}{|l|ccccc|}
\hline & Social & Culture & Personal & Psychological Consumer_behavior \\
\hline Personal & 0,980 & 0,034 & 0,000 & 0,000 & 0,000 \\
Psychological & 0,819 & 0,279 & 0,000 & 0,000 & 0,000 \\
Consumer_behavior & 0,943 & 0,088 & 2,036 & 0,519 & 0,000 \\
\hline
\end{tabular}

Source: results of SEM

\begin{tabular}{|l|ccccc|}
\hline & Social & Culture & Personal & Psychological Consumer_behavior \\
\hline Personal & 0,991 & 0,094 & 0,000 & 0,000 & 0,000 \\
Psychological & 0,926 & 0,181 & 0,000 & 0,000 & 0,000 \\
Consumer_behavior & 1,009 & 0,041 & 0,696 & $-0,263$ & 0,000 \\
\hline
\end{tabular}

Source: results of SEM 
Based on the output table above, the Social independent variable has the greatest value on the Consumer Behavior variable as an independent variable. This means that it can be concluded that the social experience of the respondent will have the greatest or most direct influence on Consumer Behavior.

Table 5. Model Estimation Results

\begin{tabular}{|lr|r|r|r|r|}
\hline & & Estimate & S.E. & C.R. & P \\
\hline Personal & $<---$ Culture & 0,098 & 0,025 & 3,950 & $* * *$ \\
\cline { 2 - 6 } Psychological & $<---$ Culture & 0,178 & 0,035 & 5,110 & $* * *$ \\
\cline { 2 - 6 } Psychological & $<---$ Social & 0,457 & 0,035 & 13,021 & $* * *$ \\
\cline { 2 - 6 } Personal & $<---$ Social & 0,515 & 0,040 & 12,733 & $* * *$ \\
\cline { 2 - 6 } Consumer_behavior <--- Culture & 0,050 & 0,130 & 0,382 & 0,703 \\
\cline { 3 - 6 } Consumer_behavior <--- Social & 0,604 & 0,334 & 1,810 & 0,070 \\
\hline
\end{tabular}

Source: results of SEM

The structural equation modeling estimation technique uses Maximum Likelihood Estimation (ML). The influence of independent variables on the dependent variable based on the research model that is built can be seen from the estimation results of the structural model. From the results above it can be seen that hypothesis 0 is rejected, so it can be concluded in this study that Culture has a significant effect on the Person. From the results it is known that Hypothesis 0 (H0) is rejected, so it can be concluded in this study that Culture has a significant effect on Psychology. From the results it is known that Hypothesis 0 (H0) is rejected, so it can be concluded in this study that Social has a positive and significant effect on Psychology. From the results it is known that hypothesis 0 (H0) is rejected. So it can be concluded in this study that Social has a positive and significant effect on the Person. From the results it is known that Hypothesis 0 (H0) is accepted, so it can be concluded in this study that culture has no effect on Consumer Behavior. From the results it is known that Hypothesis 0 (H0) is accepted, so it can be concluded in this study that Social has no effect on Consumer Behavior. From the above results it is known that Hypothesis 0 (H0) is rejected and, so it can be concluded in this study that the person has a positive and significant effect on Consumer Behavior. And from the results of the data data it is known that Hypothesis 0 (H0) is accepted. So it can be concluded in this study that Psychological does not affect Consumer Behavior.

\subsection{Analysis}

Humans everywhere are very closely related to customs and culture. Humans create culture and culture also shapes the human character itself. Culture occupies a central position in the whole order of human life. The whole building of human life and society stands on the foundation of culture. Aceh culture is always identified with Islamic teachings. However, it must be understood that before Islam arrived in Aceh, the culture there was influenced by Hindu culture from India brought by traders by sea. Therefore, between India and the people of Aceh there is a long- established cultural relationship and also ethnic relations. History writes that there were a number of traders from India who migrated to Aceh to bring along culture and art which were then practiced in Aceh. Import culture developed in Aceh by adjusting to the characteristics and traditions of local culture. Therefore there are a number of customs and cultures adopted rather than Hindu culture. Social control is important for maintaining social life. In Acehnese society, the following philosophy is the mechanism of social control (the mechanism of control), namely: Habits 
such as po teu meuruhom, hukom bah syiah kuala (custom is guarded by the king and law, meaning Islamic law, guarded by Syiah Kuala, a famous cleric). The king refers to Sulthan Iskandar Muda (died in 1637). while Syiah Kuala refers to Teuku Syech in Kuala. The biggest implication of this statement is that what is called law is Islamic (sharia) law. Any behavior that is not in accordance with Islamic law and is not consistent with adat will be punished. However, Islamic law imposed in Aceh has been adapted to adat. Therefore custom basically has a bigger role than Islamic law.

The culture of Aceh has very interesting values. The culture of Aceh is not only limited to substantial matters, but also concerns the essence of the cultural value itself. In Aceh, local cultural values mixed with foreign cultural values (especially Islamic culture that entered this region) between the two there is no longer a gap, but has been fused like two same currencies. Both of these cultural values are intended to be the cultural values of Aceh with cultural values of Islamic teachings. Assimilation of Hindu and Islamic customs and culture then gave birth to the culture and culture of Aceh as it is currently in force. The wise expression in hadih maja is mentioned, "Mate aneuk meupat jeurat, adat tam patita tamita." Meaning: "When a child dies, we know his grave; but if we lose our habits and culture, we don't know where to look." This phrase is not just for words, but the statement contains an affirmation of the importance of preserving customs and culture as a social institution in social life in Aceh. Regarding the power of the Acehnese people to hold fast to the prevailing adat, Raja Iskandar Muda was once practiced when his son who was accused of making a mistake was also punished according to the prevailing adat at that time.

The two most prominent characteristics of the people of Aceh are militancy and loyalty. This can be read through do da idi poetry. Humming sleeps the baby who teaches and invites the baby so that after he grows up he will not be afraid to fight to fight for the nation. Apart from militancy, loyalty to the people of Aceh is a high value. This is to make the Acehnese loyal. Someone must be able to show himself honest and trustworthy. There was no betrayal when he was entrusted with him. For this, a hadih maja revealed, "Ureueng Aceh nyoe hana teupeh, boh kreh jeuet ta raba. Meunyoe hate ka teupeh, bu leubeh han dipeutaba". (Acehnese, if their hearts are not offended, their honor can be touched. If their hearts are offended too much rice will not be offered).

Consumer behavior is generally influenced by people around him who provide an evaluation of the product or service and can be from the experience of the product or service that has been used. Price, quality and after-sale usually affect consumer behavior when buying products and services. Consumer behavior is influenced by cultural, social, personal and psychological factors. Most of these factors are not controlled by marketers, but must be taken into account. The cultural factors of Acehnese society are illustrated by the phenomenon where Islamic finance is used as a place to finance the family environment and where informants live. This phenomenon illustrates indirectly about consumers' assessments of Islamic finance.

The social factors of the Acehnese people are illustrated by the phenomenon in which Islamic finance as a place for financing is recommended to be chosen by the work environment, family and informant associations. Basically, although Islamic finance is recommended in the informant environment. Personal factors of the people of Aceh are illustrated by the phenomenon of personal inclinations and desires. When someone chooses Islamic finance as a place for financing, then at that time consumers or informants will want to use Islamic financial financing. Islamic finance offers financing in accordance with Islamic law and competitive prices. This is the main attraction and influences the decision of consumers to choose Islamic finance as their financing. The psychological factor of the 
Acehnese people is illustrated by the phenomenon that Islamic finance as a place for financing is indeed a personal desire, a perception of understanding Islamic law, and information about the details of sharia financing clearly provided by Islamic finance companies. This is as explained by Kotler and Keller (2009) that one of the factors influence purchasing decisions is the product or service and influences the purchasing decision is the product and brand because it provides a information about quality.

\section{Conclusion}

Based on the discussion and analysis presented in the previous chapter, the following conclusions: Culture has an insignificant influence on the behavior of the people of Aceh Province in choosing Islamic finance as a place of financing. Social has an insignificant influence on the behavior of the people of Aceh Province in choosing Islamic finance as a place of financing. Personal has a significant influence on the behavior of the people of Aceh Province in choosing Islamic finance as a place of financing. Psychological has insignificant influence on the behavior of the people of Aceh in choosing Islamic finance as a place of financing. Personal factors have a significant positive influence on the behavior of the people of Aceh in choosing Islamic finance as a place of financing. Personal intervening variables do not mediate the influence of Culture independent variables on the behavior of the people of Aceh Province in choosing Islamic finance as a place for financing. Psychological does not mediate the influence of Culture independent variables on the behavior of the people of Aceh Province in choosing Islamic finance as a place for personal finance does not mediate the influence of social independent variables on the behavior of the people of Aceh Province in choosing Islamic finance as a place of financing. Psychological does not mediate the influence of social independent variables on the behavior of the people of Aceh Province in choosing Islamic finance as a place of financing.

The obstacles experienced by the company in influencing the people of Aceh Province to choose Islamic finance as a place of financing are caused by two factors, namely internal factors which consist of the company's view of society and the public's view of the company and the constraints faced. Efforts made by Islamic finance so that the people of Aceh choose Islamic finance as a place of financing is to provide the best service to customers, who consider the customer to be king and the company provides facilities to apply for financing loans to customers. So it is expected that Islamic finance companies provide lighter margins compared to conventional financing, facilitate the process of ownership of vehicles with recollected credit and Islamic financing is more transparent in handling customers who are experiencing credit payment problems.

\section{References}

A Abdurrahman bin Nashir As Sa'di, Al Qowa'idul Fiqhiyah. Terbitan Darul Haromain, tahun $1420 \mathrm{H}$.

Abdul Rahman, Agus. Psikologi Sosial: Integrasi Pengetahuan Wahyu dan Pengetahuan Empirik. Jakarta: RajaGrafindo Persada, 2013.

Ahmadi, Abu. Psikologi Sosial. Jakarta: Rineka Cipta, 2009.

Ardhana, W. Bacaan Pilihan: Dalam Metode Penelitian Pendidikan. Jakarta: LPTKDIKTI-DIKBUD, 1987.

Arikunto, Suharsimi. Prosedur Penelitian, Suatu Pendekatan Praktis Jakarta: Rineka Cipta, 2003. 
Boyd, Harper W, dkk, Manajemen Pemasaran: Suatu Pendekatan Strategis Orientasi Global. Jakarta: Erlangga, 2000.

Cohen, J \& Cohen, P. Applied Multiple Regression Correlation Analysis for The Behavior Science. London: lowrence Erlbaum Associated Publisher, 1983.

Departemen Agama RI, Al-Quran dan Terjemahannya. Bandung: CV. Jumanatul Ali, 2005.

Djali dan Pudji Muljono. Pengukuran Dalam Bidang Pendidikan. Jakarta: PPS Universitas Negeri Jakarta, 2004.

Djazuli, H.A. Kaidah-kaidah Fikih: Kaidah-kaidah Hukum Islam dalam Menyelesaikan Masalah-masalah yang Praktis. Jakarta: Kencana. 2006.

Engel, James F. et.al., Consumer Behavior. 8th Ed. Texas: Dryden Press, 1995.

Ellyana, C.P., and Ismail. (2020). Licensing Services in the Capital Investment Services and Integrated One Door Service (Dpmptsp) Banda Aceh City. Budapest International Research and Critics Institute-Journal (BIRCI-Journal). P. 805-815.

Fred. E, Han dan Mangun Kenneth. G. Beriklan dan Berpromosi Sendiri. Jakarta: Grasindo, 2002.

Ghozali, Imam dan Fuad. Teori, Konsep dan Structural Equational Model Aplikasi dengan Program LISREL 9.10. Edisi Empat. Semarang: Universitas Diponegoro, 2014.

Hair, J.F et., al, Multivariate Data Analysis. 7th Edition. New York: Prentice Hall, 2010.

Jamaluddin, Abu al Fadl Muhammad bin Makram. Lisan al Arab. Beirut: Dar Shard.

J. Paul Peter, Jerry C. Olson. Perilaku Konsumen dan Strategi Pemasaran. Terjemahan Damos Sihombing, Edisi Keempat, Jilid I. Jakarta: Erlangga, 1999.

Kotler, Philip dan Gary Amstrong. Prinsip-Prinsip Pemasaran. Jakarta: Erlangga, 2001.

Kuncoro, Mudrajad. Metode Riset Untuk Bisnis dan Ekonomi. Jakarta: Erlangga, 2003.

Kussudyarsana. Budaya dan Pemasaran Dalam Tinjauan Pengaruh Budaya Terhadap Perilaku Konsumen, Jurnal Manajemen. Vol.12 Nomor 2, Desember 2008.

Loudon, David L dan Albert J. Della Bitta. Consumer Behavior: Concepts and Applications. 4th Ed. New York: McGraw-Hill, 1993.

Machfoedz, Mahmud. Komunikasi Pemasaran Modern. Yogyakarta: Cakra Ilmu, 2010.

Madjid, M. Dien. Catatan Pinggir Sejarah Aceh: Perdagangan, Diplomasi dan Perjuangan Rakyat. Jakarta: Yayasan Pustaka Obor Indonesia, 2014.

Najati, Muhammad Utsman. Psikologi Dalam Alquran. Bandung: Pustaka Setia, 2005.

Nokelainen, P, Structural Equation Modeling with AMOS. Finland: University of Tampere, 2009.

Pardede, Ratlan dan Renhard Manurung. Analisis Jalur (Path Analysis): Teori dan Aplikasi Dalam Riset Bisnis. Jakarta: Rineka Cipta, 2014.

Pedhazur, Elazar. MultipleRegression in Behavioral Research. New York: CBS College Publishing, 1982.

Peraturan Presiden Republik Indonesia Nomor 9 Tahun 2009 tentang Lembaga Pembiayaan. Ditetapkan di Jakarta pada tanggal 18 Maret 2009.

Pusat Pengakajian dan Pengembangan Ekonomi Islam (P3EI). Ekonomi Islam. Jakarta: Rajawali Pers, 2014.

Republika, 12 April 2015 diakses melalui www.google.com tanggal 12 Agustus 2019.

Riduan. Skala Pengukuran Variabel-Variabel Penelitian. Bandung: Penerbit Alfabeta, 2009.

Rozalinda. Ekonomi Islam: Teori dan Aplikasinya Pada Aktivitas Ekonomi. Jakarta: Rajawali Pers, 2016.

Sarwono, Sarlito W. Psikologi Lintas Budaya. Jakarta: Rajawali Pers, 2015.

Sejarah FIF, artikel diakses pada tanggal 12 Juni 2019. 
Setiadi, Nugroho J. Perilaku Konsumen: Perspektif Kontemporer Pada Motif, Tujuan dan Keinginan Konsumen. Jakarta: PrePropinsi Acehamedia, 2003.

Siswanto, dkk, Metodologi Penelitian Kombinasi Kualitatif-Kuantitatif Kedokteran \& Kesehatan: Pedoman Penyusunan Disertasi, Tesis \& Skripsi, Klaten: Boss Script, 2017.

Stanton, William J. Prinsip Pemasaran, Jilid I. Jakarta: Erlangga, 1996.

Sufi, Rusdi. Keagamaan dan Kepercayaan di Aceh pada Abad ke 19 dan ke 20, Sunaryo Purwo Sumitro (Penyusun), Dari Samudera Pasai ke Yogyakarta. Jakarta: Yayasan Masyarakat Sejarawan Indonesia, 2002.

Sugiyono. Metode Penelitian Bisnis. Bandung: Alfabeta, 1999.

Sukesi and Yunus, E. (2018). Service Quality in Public Transport Services of the Provicial Intercity Transportation (AKDP) in East Java Indonesia. Budapest International Research and Critics Institute-Journal (BIRCI-Journal). P. 161-169.

Sule, Erni Trisnawati, dkk. Manajemen Bisnis Syariah. Bandung: Refika Aditama, 2016.

Sumarwa, Ujang. Perilaku Konsumen: Teori dan Penerapannya Dalam Pemasaran. Jakarta: Ghalia Indonesia, 2003.

Supranto. Analisis Multivariat Arti \& Interpretasi. Jakarta: Penerbit Rineke Cipta, 2004.

Sutisna. Perilaku Konsumen dan Komunikasi Pemasaran. Bandung: Rosdakarya, 2001.

Tim Peneliti. Studi Implementasi Sistem Pelaporan Keuangan Perusahaan Pembiayaan. Jakarta: Biro Riset dan Teknologi Informasi BAPEPAM LK Departemen Keuangan RI, 2007.

Usman, Husaini dan Ali Akbar. Statistika. Jakarta: Bumi Aksara, 2002.

W.A. Gerungan, Psikologi Sosial. Bandung: Refika Aditama, 2009.

Walter, R. Borg \& Meredith D. Gall. Educational Research An Introduction. Fourth Edition. New York : Longman, 1983.

William G. Cochran. Sampling technique. New Delhi: Eastern Privat Limited, 1977.

Zaltman, Gerald dan Melanie Wallendorf, Consumer Behavior: Basic Findings and Management Implications. USA: John Willey \& Sons Inc, 1979. 